\title{
Interpretations of Daniel 12:1 and Perceptions of the Christian 'Other'
}

\author{
Helen Spurling
}

\begin{abstract}
This paper analyses perceptions of the Christian 'other' in rabbinic and apocalyptic traditions in the period from Constantine to the emergence of Islam. The focus is on the reception of Daniel and particularly on traditions that utilise interpretations of Dan 12:1. The essay asks to what extent these traditions present reflections on Christian rule, and/or perceptions of Christian beliefs. The article examines traditions found in Ruth Rabbah, Pirqe Mashiah and Otot ha-Mashiah, which all utilise Dan 12:1 to outline concepts of Israel's history in terms of religious status and election in relation to the 'other', and in different ways reveal perspectives on Christian Byzantine society in Late Antiquity. The different emphases of the exegetical traditions reflect historical change, especially with regard to the changing religio-political circumstances of the seventh century and an environment of increasing religious competition. In this way, one aspect of the reception of the Book of Daniel is explored to highlight an approach to Jewish-Christian relations after Constantine.
\end{abstract}

"The end was revealed to two men, and was hidden from them again, and they are these: Jacob and Daniel" (Gen. Rab. 98.2). There are few rabbinic works dedicated specifically to the interpretation of the Book of Daniel, ${ }^{1}$ yet the figure of Daniel and exegesis of the biblical book in his name has been formative for the development of eschatological ideas within rabbinic traditions. As John Collins recently noted, the reception of the Book of Daniel is an area that still needs further exploration, especially given its importance not only for rabbinic concepts of the end of the world, but also within Christian apocalyptic teachings of Late Antiquity. ${ }^{2}$ The reception of Daniel can then provide an important insight into rabbinic Judaism in the postConstantinian age, and offers fertile ground for the exploration of Jewish-Christian relations in the period up to the Arab conquests of the seventh century. This paper aims to broaden the discussion of the reception of Daniel through examination of rabbinic and apocalyptic traditions that utilise interpretations of Dan 12:1, asking to what extent these traditions present reflections on Christian rule, and/or perceptions of Christian beliefs in this period. ${ }^{3}$ In particular, the focus will be on traditions that are concerned with questions of religious status and election, and the perspectives they may reveal on Christian Byzantine society in Late Antiquity through an eschatological lens.

Despite Collins' correct assessment that the reception of the Book of Daniel needs more scholarly attention, there are certainly key motifs arising from this biblical book that have been thoroughly examined for their exegetical development either within Jewish interpretations, Christian literature, or for possible relationships between Jewish and Christian exegesis. For example, the concept of the 'son of man' of Dan 7:13 has been explored particularly for how

\footnotetext{
${ }^{1}$ For example, most cited is Ma'aseh Daniel, a late medieval work on the Book of Daniel; cf. Adolph Jellinek, Bet ha-Midrasch (2nd ed.; Jerusalem: Bamberger \& Wahrmann, 1938), 5:117-130. See also Lorenzo DiTommaso, The Book of Daniel and the Apocryphal Daniel Literature (Leiden: Brill, 2005) for a survey of ancient and medieval apocryphal Daniel literature.

${ }^{2}$ In 2002, Collins noted: "The history of interpretation of Daniel is a rich field that has only recently begun to attract serious attention," John J. Collins and Peter W. Flint, eds., The Book of Daniel: Composition and Reception (Leiden: Brill, 2002), 1:12. The second volume of this edited collection offers six case studies as a means of addressing this issue. John Reeves also noted the significance of the reception of the Book of Daniel as an area of study, but the need for more work in this area, John C. Reeves, Trajectories in Near Eastern Apocalyptic: a postrabbinic Jewish apocalypse reader (Leiden; Boston: Brill, 2006), viii.

${ }^{3}$ The research behind this study comes from a broader exploration of the reception of Daniel 12 as a whole, but, given the quantity of material for discussion the focus here has been limited to Dan 12:1.
} 
the term is used in the New Testament, but also as a point of interpretative contention between Jews and Christians on the question of messianism. ${ }^{4}$ Another key motif that has received a lot of consideration is the identification of the fourth kingdom of Daniel 2 and 7, which was frequently connected to the fate of Edom in rabbinic sources. ${ }^{5}$ The interpretation of Daniel in relation to the Roman Empire was already made by Josephus in Ant. 10.276-7, and references to the fourth kingdom in both rabbinic and Christian literature of the period have often been understood to comment on the historical-political reality of pagan Roman or subsequently Christian Roman/Byzantine rule of Late Antiquity. ${ }^{6}$ A third major area of investigation has been the nature of resurrection based on readings of Dan 12:2. Interpretation of those "who sleep in the dust of the earth" is prominent in rabbinic and patristic concepts of resurrection, which are extensive and complex, with questions arising regarding a physical or spiritual resurrection, the time and place of resurrection, and who may take part. $^{7}$

It is, nevertheless, worth exploring aspects of interpretation of Daniel beyond the motifs outlined above. It is clear that Daniel 12 in particular has an important place in rabbinic exegesis due to its major themes: the time of redemption, divine justice, the nature of righteousness, and reward and punishment at the end of time. Indeed, chapter 12 features as a major pool of proof texts throughout the range of midrashim from the tannaitic to the geonic period and beyond, primarily, although not solely, for the development of eschatological ideas in rabbinic traditions. ${ }^{8}$ For example, in addition to the theme of resurrection mentioned above, a major exegetical approach is consideration of the nature of the righteous based on Dan 12:3: "Those who are wise will shine like the brightness of the firmament, and those who bring the many to righteousness, like the stars for ever and ever." Dan 12:3 is the most frequently cited proof text from this chapter in classical midrashim and is used to explore the characteristics of the righteous. The righteous are identified with a variety of groups depending on the tradition, ranging from the "seed of Jacob" to "all Israel" and from the seven companies of righteous

\footnotetext{
${ }^{4}$ The scholarship on this topic is vast; for some select recent works, see Larry W. Hurtado and Paul L. Owen, Who is this Son of Man? (London; New York: T\&T Clark International, 2011), Adela Y. Collins and John J. Collins, King and Messiah as Son of God (Grand Rapids: Eerdmans Publishing Co., 2008), William Horbury, Messianism among Jews and Christians (London; New York: T\&T Clark, 2003) and Collins and Flint, Book of Daniel, 490-527, 528-549.

${ }^{5}$ For example, see Gen. Rab. 44.15, 44.17, 76.6, 99.2 and Lev. Rab. 13.5; cf. note 6 and the article by Morgenstern in this volume.

${ }^{6}$ It seems that the language of the fourth kingdom applied equally to pagan and Christian Rome and there is often little to distinguish between the two as the terminology did not tend to change with the Christianisation of Rome. See Wout J. van Bekkum, "Four Kingdoms will Rule: Echoes of Apocalypticism and Political Reality in Late Antiquity and Medieval Judaism," in Endzeiten: Eschatologie in den monotheistischen Weltreligionen, ed. Wolfram Brandes and Felicitas Schmieder (Berlin; New York: de Gruyter, 2008), 101-118, Uwe Glessmer, "Die 'Vier Reiche' aus Daniel in der Targumischen Literatur," in Collins and Flint, Book of Daniel, 468-489, and Robert Goldenberg, The Nations that Know Thee Not: Ancient Jewish Attitudes towards Other Religions (Sheffield: Sheffield Academic Press, 1997), 96-98; cf. Hippolytus, Scholia on Dan. 7.7, Jerome, Comm. Dan. 7.7 and Theodoret of Cyrus, Comm. Dan. 7.7, which all explicitly equate the fourth kingdom with Rome. Interestingly, Ephrem the Syrian understands the fourth beast to refer to Alexander (Comm. Dan. 7.7) and Aphrahat identifies the fourth beast with the sons of Shem who are equated with the descendants of Esau, the current government (Dem. 5.10).

${ }^{7}$ See, for example, Harry Sysling, Tehiyyat ha-metim: the resurrection of the dead in the Palestinian Targums of the Pentateuch and Parallel Traditions in Classical Rabbinic Literature (Tübingen: Mohr Siebeck, 1996), Alan Avery-Peck and Jacob Neusner, eds., Death and Afterlife in the Early Rabbinic Sources: The Mishnah, Tosefta, and early Midrash Compilations (Leiden: Brill, 2000), and Günter Stemberger, "Zur Auferstehungslehre in der rabbinischen Literatur," Kairos 15 (1973): 238-266.

${ }^{8}$ While Daniel 12 is crucial in the development of eschatological traditions, the chapter has also been mined for proof texts in non-eschatological contexts. For example, Dan 12:7 is frequently utilised in discussions on the correct procedure for swearing oaths; see Gen. Rab. 43.9, Tanh Lek Lekha 13, b. Naz. 3b and Midr. Pss. 17.10; cf. Pesiq. Rab. 31.9 where the discussion of oaths is still in an eschatological context and highlights the recurrent pledge that redemption will come for God's people.
} 
men who will stand in the presence of God in the world-to-come to specifically the rabbis themselves, which are interpretations that can reflect a concern to justify the position and authority of the referents. ${ }^{9}$ In Dan 12:4, the eponymous hero is famously told to "shut up the words, and seal the book until the time of the end," which has led to speculation on the date and timings of redemption in rabbinic traditions, including the assertion that the time of the end was revealed to Daniel, the declaration that there is no knowledge of the end, and the statement that the time of redemption is hidden. ${ }^{10}$ This is further developed through debate over eschatological timetables based on Dan 12:7 and 12:11-13. An interesting aspect of this exegesis is the well-attested tradition that the Messiah will disappear during the time of tribulation (usually) for a period of forty-five days while Israel eat the roots of broom in the wilderness, which is based on calculating the difference between the 1,335 days of Dan 12:11 and the 1,290 days of Dan 12:12. ${ }^{11}$ These themes provide an indication that Daniel 12 has a lot to offer in terms of reception history, and are all avenues of potential analysis for perspectives on 'self' and 'other', but the focus here is an initial discussion of rabbinic and apocalyptic interpretations of Dan 12:1, which states:

\section{ובעת ההיא יעמד מיכאל השר הגדול העמד על בני עמך והיתה עת צרה אשר לא נהיתה מהיות גוי עד

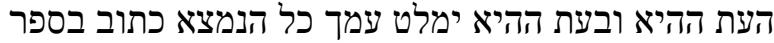

At that time, Michael, the great prince, the one who protects the children of your people, will arise. There will be a time of distress such as has not happened since there was a nation until that time. But at that time your people will be delivered-everyone who is found written in the book.

Dan 12:1 introduces a number of major themes that are explored in more detail within rabbinic and apocalyptic traditions: the role of Michael as defender of God's people and his function at the end of time; the end of the world as a time of tribulation; and concepts of salvation and election that serve as a basis for discussion of divine justice and the relationship between God and his people. ${ }^{12}$ A further topic of interest, also for exploring perspectives on Jewish-Christian relations, is the ways in which Dan 12:1 is used to support concepts of history, and the role of key players, and of course principally Israel, within the portrayal of history. ${ }^{13}$ In particular,

\footnotetext{
${ }^{9}$ For example, Dan 12:3 is identified as referring to the seed of Jacob in Gen. Rab. 65.21, all Israel in Pesiq. Rab. 11.5 and Exod. Rab. 2.13, the seven companies of righteous men in Sifre Deut. 10 and 47, Lev. Rab. 30.2, Pesiq. Rab Kah. 27.2, Pesiq. Rab. 51.4, Midr. Pss. 11.6, and the rabbis in Lam. Rab. proem 23. There are also diverse referents in Christian writings, see Pachomius, Instructions 1.32, Ambrose, On the Christian Faith 2.2.24, Jerome, Comm. Dan. 12.1-3 and Theodoret of Cyrus, Comm. Dan. 12.3.

${ }^{10}$ See, for example, Gen. Rab. 98.2, Tanh Wayera 6, Midr. Pss. 31.7 and 74.3; cf. Irenaeus, Against Heresies 4.26.1, Jerome, Comm. Dan. 12.4 and Theodoret of Cyrus, Comm. Dan. 12.4.

${ }^{11}$ For example, see Pesiq. Rab Kah. 5.8, Pesiq. Rab. 15.10, Ruth Rab. 2.14 and 5.6, Song Rab. 2.25, Num. Rab. 11.2 and apocalyptic midrashim such as Sefer Zerubbabel, Pirqe Mashiah and Nistarot R. Shimon ben Yohai; cf. interpretations based on the timings in Dan 12:11-12 in Cyril of Jerusalem, Catechetical Lectures 15.16-17, John Chrysostom, Discourses against Judaising Christians 5.8.4, Jerome, Comm. Dan. 12.12 and Theodoret of Cyrus, Comm. Dan. 12.12.

${ }^{12}$ Dan 12:1 is part of a larger unit in 12:1-4, which Oegema has described as providing the basic contents of apocalyptic thinking, Gerbern Oegema, Zwischen Hoffnung und Gericht: Untersuchungen zur Rezeption der Apokalyptik im frühen Christentum und Judentum (Düsseldorf: Neukirchener Verlag, 1999), 3-4; see John J. Collins, Daniel: a commentary on the book of Daniel (Minneapolis: Fortress Press, 1993).

13 Oegema has described a rabbinic "eschatologically oriented concept of history", attempting to provide an explanation of the place of Israel under the rule of world powers since the destruction of the Temple. He notes that "rabbinic Judaism is able to both focus its Realpolitik on the historical problems and political balances of power in the present (in this world) and at the same time to orient eschatologically (or utopically) toward the future (the world to come)." Gerbern Oegema, Apocalyptic Interpretation of the Bible (London; New York: T\&T Clark International, 2012), 168.
} 
further questions include how the biblical text is used to promote different understandings of the trajectory of Jewish history, and the relationship between Israel and God, and Israel and other nations or social groups, as part of these narratives. This is turn tells us much about how the redactors viewed their place and status in society, their concerns and anxieties and hopes for the future, notably in relation to the Roman/Byzantine Empire but also as part of world history.

A tradition on the role of Michael in Israel's history as found in Ruth Rab. proem 1 will be the first interpretation assessed here. Ruth Rabbah is usually dated to fifth or sixth century Palestine,${ }^{14}$ and so was compiled at the height of the Christian Byzantine Empire when the legal position of Jews became increasingly difficult, as reflected in the Theodosian and Justinian legal corpus. ${ }^{15}$ The tradition in Ruth Rabbah has a number of parallels, including a version preserved in Pirqe Mashiah, which is a late midrashic compilation on the end of the world and of interest for its interpretation of Dan 12:1. As with many late midrashim, dating is uncertain, but Pirqe Mashiah is commonly assigned to the seventh or eighth centuries, and, while it refers to the Arab conquests, its primary concern is the downfall and punishment of 'Edom'. ${ }^{16}$ Discussion will then turn to analysis of the use of Dan 12:1 in Otot ha-Mashiah, which is a late compilation of apocalyptic traditions that are structured in the form of ten signs of the messianic age. Otot ha-Mashiah has a complex textual history, but is also often dated to the seventh century at the time of the so-called revival of apocalyptic literature as a result of the Sasanian and Arab conquests, and arguably a time of retreat for the Byzantine Empire. ${ }^{17}$ The difficulties arising from questions of transmission of traditions and dating rabbinic and apocalyptic compilations are widely known and need no rehearsal here. ${ }^{18}$ Yet an examination of the variations in motifs and interpretations can allow for assessment of potential emphases in the selected traditions, and consideration of what they may suggest, if anything, about perspectives on the Christian world. ${ }^{19}$ The traditions found in Ruth Rabbah, Pirqe Mashiah and

${ }^{14}$ A fifth century date is advocated by Myron B. Lerner, "The Works of Aggadic Midrash and the Esther Midrashim," in The Literature of the Sages, Part 2, ed. Shmuel Safrai (Assen: Royal van Gorcum and Fortress Press, 2006), 149-150, while Günter Stemberger prefers a date around 500 in Hermann Strack and Günter Stemberger, Introduction to the Talmud and Midrash (Edinburgh: T\&T Clark, 1991), 344.

${ }^{15}$ It is important to note that the legal corpora do not represent law as universally practiced, and include efforts to protect Jews (e.g. Theodosian Code 16.8.20 and 16.10.24) as well as regulate their status and activities (e.g. Theodosian Code 16.8.18 and 16.8.29). See the article by Ribary in this volume.

${ }^{16}$ For more detail on Pirqe Mashiah, see Helen Spurling, "A Revival in Jewish Apocalyptic? Change and continuity in the seventh-eighth centuries with special reference to Pirqe Mashiah," in Apocalypticism and Eschatology in Late Antiquity: Encounters in the Abrahamic Religions, 6th-8th Centuries, ed. Hagit Amirav, Emmanouela Grypeou and Guy Stroumsa (Leuven, Peeters Publishers, 2017), 163-186, and Reeves, Trajectories, 149-169.

17 On dating Otot ha-Mashiah, see Alexei M. Sivertsev, Judaism and Imperial Ideology in Late Antiquity (Cambridge: CUP, 2011), 50-52; cf. Ra'anan S. Boustan, "The Spoils of the Jerusalem Temple at Rome and Constantinople: Jewish Counter-Geography in a Christianizing Empire," in Antiquity in Antiquity: Jewish and Christian Pasts in the Greco-Roman World, ed. Gregg Gardner and Kevin L. Osterloh (Tübingen: Mohr Siebeck, 2008), 364.

${ }^{18}$ For recent overviews, see Martin Goodman and Philip Alexander, eds, Rabbinic Texts and the History of LateRoman Palestine (Oxford: OUP, 2010), Günter Stemberger, "Aktuelle Probleme in der Erforschung der rabbinischen Literatur: Überlegungen zur Abgrenzung von Werk, Redaktion, Textgeschichte," Frankfurter Judaistische Beiträge 35 (2009): 1-18, Catherine Hezser, "Classical Rabbinic Literature," in The Oxford Handbook of Jewish Studies, ed. Martin Goodman (Oxford: OUP, 2005), 115-140, and Carol Bakhos, ed., Current Trends in the Study of Midrash (Leiden: Brill, 2006), esp. 161-187.

${ }^{19}$ As is well-known, rabbinic sources are rarely explicit about engagement with Christianity, even leading to the suggestion that there is no interest in Christianity on the part of the rabbis. The allusive nature of the evidence means that it is necessary to argue for potential engagement with Christian traditions on a case by case basis, and acknowledge that purely internally-focused rabbinic concerns are frequently presented. See an approach to this issue in Emmanouela Grypeou and Helen Spurling, The Book of Genesis in Late Antiquity: Encounters between Jewish and Christian Exegesis (Leiden: Brill, 2013), esp. 1-38. 
Otot ha-Mashiah make a useful basis for investigation as they outline concepts of Israel's history - beyond the more commonly discussed interpretations of the four kingdoms of Daniel - and, in different ways, link this history to the function of Michael in Dan 12:1.

\section{Ruth Rabbah}

Ruth Rab. proem 1 begins with citation of Ruth 1:1 as the verse for comment: "And it came to pass, in the days that the judges judged" (ויהי בימי שפט השפטים). In typical midrashic style, this verse is immediately connected to Ps 50:7 as a verse that can elucidate Ruth 1:1: "Hear, OMy people, and I will speak; O Israel, and I will testify against you" (שמעה עמי ואדברה ישראל ואעידה בך). The two verses provide a link between judges and testimony, and open the way for a brief statement on courtroom procedures. This is immediately followed by a tradition concerning the name and status of Israel. The citation of Ps 50:7 is used to explore the fact that Israel was originally named after their ancestor, as with other nations, but in Ps 50:7 are called " $M y$ people" by God. When God says "and I will speak" (ואדברה) in the Psalm, it is understood as an allusion to Sinai, and linked with Exod 24:7 when Israel accepted the Torah that God 'spoke' and they promised to 'hear' or obey: "and they said, all that the Lord spoke, we will do and we will hear" (ויאמרו כל אשר דבר י' נעשה ונשמע). Thus, it is due to acceptance of Torah that Israel merits the honour of being called "My people". The midrash goes on to record a concept of history based on exegesis of Ps 50:7 and several proof texts, including Dan 12:1:

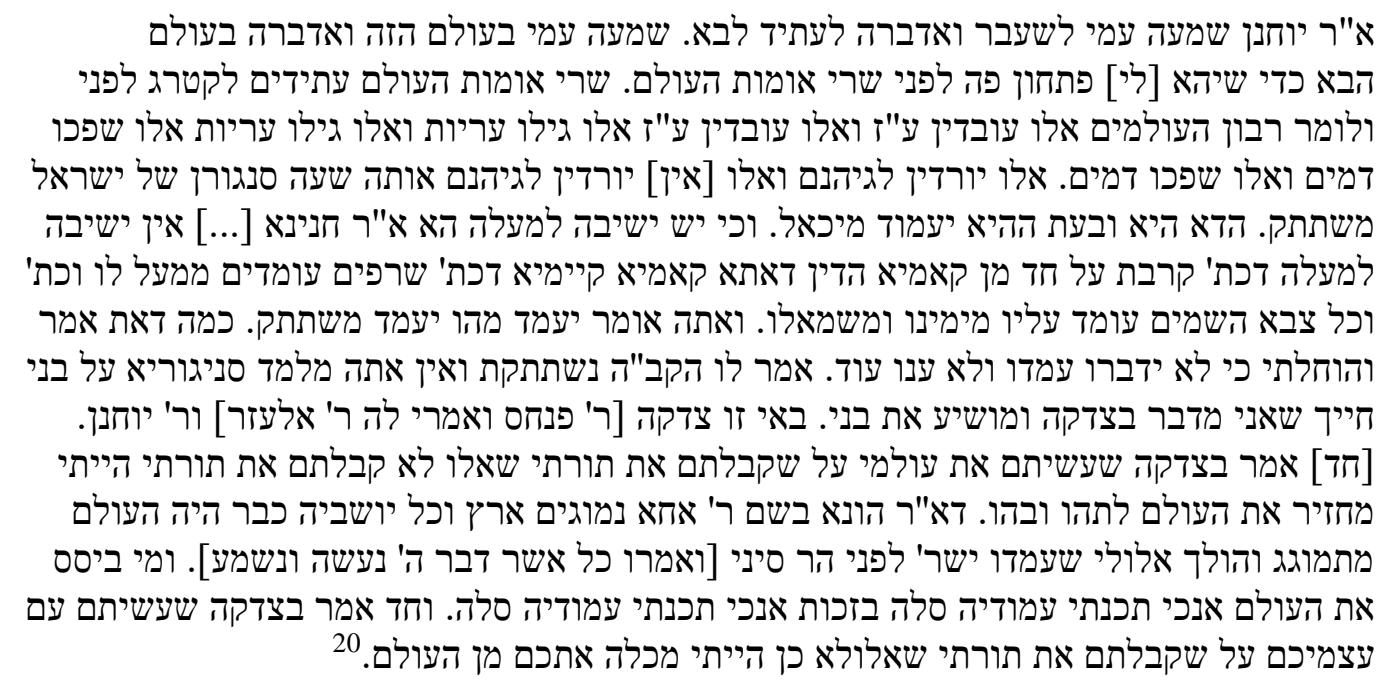

R. Yohanan said: "Hear, O My people" - in the past, "and I will speak" - in the future. "Hear, $O$ My people" - in this world, "and I will speak" - in the world-to-come, in order that [I] may have a retort before the princes of the peoples of the world. The princes of the peoples of the world will bring charges before Me, and say: Master of the worlds, these (the nations) have committed idolatry and they (Israel) have committed idolatry, these have uncovered nakedness and they have uncovered nakedness, these have shed blood and they have shed blood. Why do these go down to Gehinnom, yet they do [not] go down to Gehinnom?' At that moment the advocate of Israel will be silent. This is the meaning of "At that time Michael will stand up" (Dan 12:1). Is it so that there is sitting in heaven? Did not R. Hanina [...] say: There is no sitting in heaven, as it is written, "I came near to one of "qa'amaya"" (Dan 7:16). The meaning of 'qa'amaya" is 'that stood by', as it is written, "Seraphim stood above him" (Isa 6:2), and it is written, "All the host of heaven standing on His right hand and on His left" (2 Chr 18:18)? But it says "will stand up"! What then is the meaning of

${ }^{20}$ The passage of Ruth Rab. proem 1 is from Myron B. Lerner, "The Book of Ruth in Aggadic Literature and Midrash Ruth Rabba," (Ph.D. Diss., The Hebrew University of Jerusalem, 1971), which is a critical edition of MS Oxford 164 and Genizah fragments. 


\begin{abstract}
"will stand up"? 'be silent', in accordance with what is said, "Shall I wait because they speak not, they stand and do not answer further?" (Job 32:16). The Holy One, blessed be He, will say to him: You have been brought to silence and you do not speak in defence of My children. By your life, " $I$ speak righteousness" (Isa 63:1) and will save My children! On account of what righteousness? [R. Pinhas and others say R. Eliezer] and R. Yohanan: [One] said: The righteousness that you wrought for My world because you accepted My Torah, because if you had not accepted My Torah, I would have returned the world to formlessness and nothingness. Another interpretation: R. Huna in the name of R. Aha: "When the earth and all its inhabitants are dissolved" (Ps 75:4). The world would have been dissolving long ago were it not that Israel stood before Mount Sinai ["and they said, all that the Lord spoke, we will do and we will hear" (Exod 24:7)]. Who gave the world a firm basis? "I, I established its pillars. Selah" (Ps 75:4). By the merit of 'I', "I have established its pillars. Selah." The other said: The righteousness that you wrought for yourselves because you accepted my Torah, as, if it were not so, I would have destroyed you from the world. ${ }^{21}$
\end{abstract}

R. Yohanan understands Ps 50:7 as alluding to the fact that Israel heard God speak in the past at Sinai ("Hear, O My people"; שמעה עמי) when they accepted the Torah, but also to God speaking on behalf of Israel in the future ("and I will speak"; ואדברה). ${ }^{22}$ The acceptance of Torah means that God will have a retort when the angelic advocates for the nations bring charges against Israel in the divine court. ${ }^{23}$ In the world-to-come, the angelic prosecutors will point out that Israel has behaved just as other nations with regard to idolatry, sexual immorality and bloodshed, and so question why Israel merits Eden while the nations are rewarded with Gehinnom. It is here that Dan 12:1 is used to explain the role of Michael in these proceedings. He is described as the "advocate of Israel" (סנגורן של ישראל), which is in line with the function of Michael in Dan 12:1 as a defender of Israel and is understood here in a judicial context. ${ }^{24}$ However, in Ruth Rabbah, Michael is unable to answer the charges brought by the opposing angelic counsellors. ${ }^{25}$ Interpretation focuses on the expression "Michael will stand up" (יעמד (מיכאל) in Dan 12:1. The verb עמד can have a variety of meanings, such as 'arise', 'appear', 'come to prominence' or literally 'stand up'. However, the literal understanding of 'stand up' is rejected because three proof texts - Dan 7:16, Isa 6:2 and 2 Chr 18:18 - all describe heavenly beings standing and so indicate that there is no sitting - only standing - in the heavenly court. Instead, the phrase "Michael will stand up" (יעמד מיכאל) is understood to mean that he stands silent. This is proven by Job 32:16 where the interlocutors of Job stand silently and are unable to answer his arguments (כי עמדו לא ענו עוד). The use of this proof text connects standing with silence, but may also suggest an inability rather than unwillingness to answer. Due to Michael's failure to defend Israel, God himself intervenes, ${ }^{26}$ based on Isa 63:1 as another time God speaks.

\footnotetext{
21 This marks the end of this particular interpretation, but the proem continues with a series of alternative interpretations based on different proof texts. They address the same theme of the importance of acceptance of Torah, followed by further interpretation of Ps 50:7, before linking back to Ruth 1:1 as the original verse for comment.

22 The verb שמע has the sense of both 'hear' and 'obey', and suggests that acceptance of Torah is not sufficient Israel must also keep the covenantal obligations.

${ }^{23}$ The concept of angelic representatives for each nation is famously found in the Book of Daniel; see Dan 10:13 and 10:20-21, which describe Michael as "one of the chief princes" and mention the prince of Persia and the prince of Greece as titles for the angels that protect these empires. See Meira Z. Kensky, Trying man, Trying God: The Divine Courtroom in Early Jewish and Christian Literature (Tübingen: Mohr Siebeck, 2010), Yehuda Septimus, On the Boundaries of Talmudic Prayer (Tübingen: Mohr Siebeck, 2015), esp. 45-88 on guardian angels, and Mika Ahuvia, "Israel Among the Angels" (Ph.D. Diss., Princeton University, 2014).

${ }^{24}$ The use of סניגוריא and related terminology reflects a Graeco-Roman environment, see Kensky, Trying man, Trying God, 306-319 and Richard Hidary, Rabbis and Classical Rhetoric (Cambridge: CUP, 2018), esp. 240-263 on heavenly advocates. Dan 12:1 provides the basis for Michael's position in rabbinic tradition as the guardian of the Jews; cf. b. Yoma 77a, Esth. Rab. 7.12 and 10.9, Pesiq. Rab. 44.10, Pirqe R. El. 26, 33, 36, 37, 38, 42, 50, Tg. Ps.-J. Gen 32:25 and 38:25-6, Exod. Rab. 18.5, Sefer Eliyahu, Sefer Zerubbabel and Otot ha-Mashiah.

25 cf. Pirqe Mashiah, Exod. Rab. 18.5 and Midr. Pss. 20.3.

${ }^{26} \mathrm{cf}$. Tanh Ki Tissa 32 in which Moses speaks in defence of Israel, but God is the advocate in the future world and Tanh Qedoshim 1 where God speaks in defence of Israel. See also the famous courtroom drama involving the
} 
God declares that "I speak righteousness" (אני מדבר בצדקה) in order to save His people, and this righteousness is the merit gained by Israel for accepting the Torah. ${ }^{27}$ This leads to two rabbinic views on the disaster averted as a result. One opinion is that Israel will be saved because their commitment prevented the destruction of creation. This view is further supported by an alternative interpretation that indicates that creation would have been undone, based on Ps 75:4, if Israel had not accepted the Torah at Sinai as stated in Exod 24:7. The other rabbinic view is that Israel prevented the destruction of themselves. ${ }^{28}$

So is there anything in Ruth Rab. proem 1 to suggest engagement with the Christian 'other'? There are three possible ways in which the passage points the audience to the Christian Roman world of its time: first, by formulating the exegesis in such a way that the Roman authorities would come to the mind of the audience; secondly, through a choice of proof texts that have a long history in anti-Christian polemics; and finally, by the casting of Michael as an unsuccessful defender of Israel.

First, there is clearly no explicit reference to Christianity or Christian rule, and it is perfectly possible to read this passage as a statement about Israel's status in respect to the general nations of the world at the end of time. However, generic terminology allows for the referent to change in light of contemporary circumstances, and those nations closest to home would be in the mind of the audience. As such, when living under Byzantine rule, discussion of a trial involving the nations of the world would naturally put the Christian Byzantines at the forefront of the list of those nations. ${ }^{29}$ Furthermore, the trial format and the concept of history in the tradition in Ruth Rabbah ensures that questions of the status of Israel in relation to competing claims can be understood. The tradition presents a dualistic view of Israel and the nations; the statement that God calls Israel "My people" implies the exclusion of other groups from this relationship, which is manifested in their ultimate fate. In this way, Ruth Rabbah represents a rabbinic concept of election history whereby Israel is deemed righteous and will receive the reward of Eden because of their specific covenantal relationship with God and their acceptance of Torah. The acceptance and proper understanding of Torah is of course a key and longstanding point of contention in the early history of Jewish-Christian relations, and this lies at the heart of the outcome of the trial and how the fate of the nations is determined in Ruth Rabbah. ${ }^{30}$

Secondly, the nations of the world may be portrayed in a general way, but the choice of biblical proof texts for this view of election history is significant. The intervention of God is based on Isa 63:1, which is a prophecy of vengeance by God against Edom, which nation He has destroyed as signified by His bloodstained clothes. Although hotly debated as to the precise

nations of the world in b. A.Z. 2a-3b. See Dov Weiss, Pious Irreverence: Confronting God in Rabbinic Judaism (Philadelphia: University of Pennsylvania Press, 2017).

${ }^{27}$ Thus, God defends Israel by himself without aid from Michael. Interestingly, Isa 63:1-6 emphasises that God takes vengeance against the nations 'alone', and so the use of Isa 63 further highlights the point that God ultimately acts alone, whether in his defence of Israel or his prosecution of the nations.

${ }^{28}$ For Torah as a means of deliverance from punishments in Gehinnom cf. Gen. Rab. 44.21, Pesiq. Rab. 15.2, $b$. Pesah 42b and Midr. Pss. 52.2. On the acceptance of Torah by Israel, but its rejection by the nations of the world cf. Mek. Bahodesh 5, Sifre Deut. 343, Pesiq. Rab. 21:2/3, b. A.Z. 2a-3b, Pirqe R. El. 41 and Tanh Buber Berakhah 3; see Peter Schäfer, "Israel und die Völker der Welt," Frankfurter Judaistische Beiträge 4 (1976): 32-62.

${ }^{29}$ See a similar line of argument in van Bekkum, "Four Kingdoms," 104, and Goldenberg, Nations that Know Thee Not, 96-98.

${ }^{30}$ The 'true' understanding of scripture is a major theme in Christian writings from the earliest periods, see, for example, Epistle of Barnabas 2, 9, 10 and 15, Justin Martyr, Dialogue with Trypho 18-24, 29, 46, Tertullian, Against the Jews 3-6; for overviews of this key issue, see Charles Kannengiesser, Handbook of Patristic Exegesis: The Bible in Ancient Christianity (Leiden; Boston: Brill, 2004), Magne Saebo, ed., Hebrew Bible/Old Testament (Göttingen: Vandenhoeck and Ruprecht, 2000), and Martin J. Mulder and Harry Sysling, eds., Mikra: Text, Translation, Reading and Interpretation of the Hebrew Bible in Ancient Judaism and Early Christianity (Philadelphia: Fortress Press, 1988). 
nature of the symbolism, mention of Edom in rabbinic traditions is frequently understood as a reference to pagan Rome or Christian Rome/Byzantium, and Isa 63:1 is a prominent proof text in this regard. ${ }^{31}$ As such, the use of Isa 63:1 connects God's judicial intervention on behalf of Israel in the heavenly court with his military vengeance against 'Edom' in the eschatological future, and in so doing points to Israel's primary adversary.

Thirdly, the portrayal of Michael hints at potential connections with Christian representations of this biblical character. Michael is the advocate of Israel in a legal contest with the princes of the nations, but he fails to mount a successful defence, which is very critical of Michael's abilities. As a result, Michael is subordinated to God who is the ultimate defender of his people. This could be viewed in light of Christian claims for Michael as the defender of Verus Israel..$^{32}$ Indeed, Christian perspectives that Michael was the guardian of Jews, but that his protection has now extended to Christians are early and widespread, as manifested in works such as Shepherd of Hermas, Similitudes 8.3.3, Origen, Comm. Matt. 14.21 and Theodoret of Cyrus, Comm. Dan. 12.1. The approach in Ruth Rabbah both properly claims Michael for Israel in line with biblical teaching, but also clearly relativizes his position in the divine court as he cannot provide an answer in the way that God is able to do. ${ }^{33}$

Overall, Christian rule or beliefs are not explicitly addressed, but the typically allusive nature of the evidence allows for a range of reading strategies. One approach is to read the trial, competing claims and view of election history centred on Torah in Ruth Rabbah as a perspective on the place of Israel in their contemporary Christian Byzantine society, accompanied by claims for a change in Israel's status and fulfilment of scripture when it matters most - in the world-to-come.

\section{Pirqe Mashiah}

The tradition in Ruth Rabbah is paralleled in a number of compilations, including Pirqe Mashiah, Exod. Rab. 18.5 and Midr. Pss. 20.3. The tradition as transmitted in Pirqe Mashiah is particularly interesting because it discusses many of the same themes as the tradition in Ruth Rabbah, but uses more explicit terminology as to the key characters involved in the heavenly trial. It also provides an innovative interpretation of Dan 12:1. ${ }^{34}$ Pirqe Mashiah opens with an

\footnotetext{
${ }^{31}$ References to Edom need to be analysed on a case by case basis with regard to possible symbolism; select studies on this topic include: Carol Bakhos, "Figuring (out) Esau: The Rabbis and Their Others," Journal of Jewish Studies 58.2 (2007): 250-262, Mireille Hadas-Lebel, Jerusalem against Rome (Leuven; Dudley MA: Peeters, 2006), Gerson Cohen, "Esau as Symbol in Early Medieval Thought," in Jewish Medieval and Renaissance Studies, ed. Alexander Altmann (Cambridge MA: Harvard University Press, 1967), 19-48, and Helen Spurling, “The Biblical Symbol of Edom in Jewish Eschatological and Apocalyptic Imagery," in Sacred Text: Explorations in Lexicography, ed. Angel Urban and Juan Pedro Monferrer-Sala (Frankfurt: Peter Lang, 2009), 271-299; cf. notes 5 and 6 and the article by Morgenstern in this volume.

${ }^{32}$ As Darrell Hannah notes, "his guardianship of Christians derives from the assumed continuity of the Church with the saints and prophets of the OT," Darrell Hannah, Michael and Christ (Tübingen: Mohr Siebeck, 1999), 165.

${ }^{33}$ For a detailed discussion of Michael traditions in relation to christology, see Hannah, Michael and Christ. Michael is sometimes identified with Metatron in rabbinic sources, an identification that has also been assessed for a potential relationship with Christian traditions, see Peter Schäfer, The Jewish Jesus: How Judaism and Christianity Shaped Each Other (New Jersey: Princeton University Press, 2012), 103-149, and Reeves, Trajectories, 179-186.

${ }^{34}$ Pirqe Mashiah is found in Jellinek, Bet ha-Midrasch, 3:68-78. Jellinek has reproduced Pirqe Mashiah from a collection dated to 1743 from Salonica. Moses Buttenwieser found BHM 3:68.6-28 beginning with פעם "on one occasion" and closing with בכ"ב אותיות "in the twenty-two letters" in MS Bayerische Staatsbibliothek Cod. Hebr. 222, 83a-84a as the middle part of a different aggadic collection with the title מעם אחר, Moses Buttenwieser, Die hebräische Elias-Apokalypse (Leipzig, 1897), 10; cf. Yehuda Even-Shemuel, Midreshe Ge'ulah (JerusalemTel Aviv: Bialik Insitute, 1953-4²), 332-344.
} 
outline of the basis for the salvation of Israel. Elijah comes to R. Yose's bet ha-midrash, but he is distraught and tells the rabbi of a scene he has witnessed in heaven. ${ }^{35}$ God and Michael were reading the consolation passages in the Book of Isaiah, ${ }^{36}$ but were interrupted by Sammael bringing accusations against Israel. Elijah confronted Sammael but he responded only with violence. Rabbi Yose offers an interpretation of these events, based on a paraphrase of Isa 57:12: "I will proclaim your righteousness, and all his works, and they will not account for anything." ${ }^{37}$ The righteousness of Israel will be proclaimed, in accordance with Isaiah, and anything that Sammael may do will account for nothing. ${ }^{38}$ Interestingly, in Pirqe Mashiah, Sammael is explicitly identified with the "prince of Rome" (סמאל שר של רומי), the angelic advocate of the Roman and subsequently Byzantine Empire. ${ }^{39}$ Indeed, the violent actions of Sammael towards Elijah are connected to his position as prince of Rome. This leads to an alternative interpretation, which outlines a disputation between Sammael and Michael, who is defending Israel against the charges Sammael has brought:

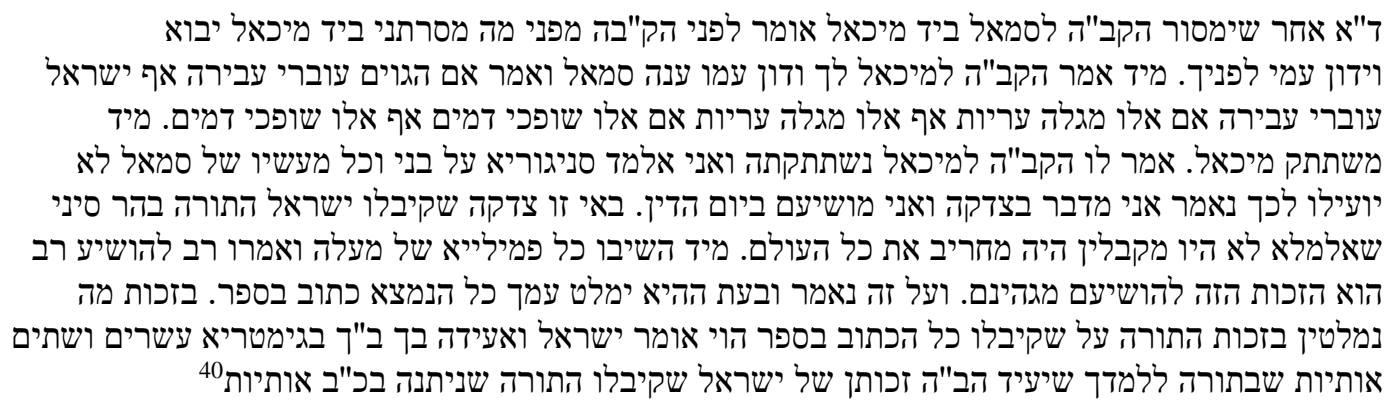

Another interpretation: After the Holy One, blessed be He, surrenders Sammael into the hand of Michael, he will say before the Holy One, blessed be He: Why have you delivered me into the hand of Michael? Let him come and argue with me before you! At once, the Holy One, blessed be He, will say to Michael: Go and dispute with him! Sammael will answer and say: If the nations are transgressors, then Israel are also transgressors, if these uncover nakedness, so also do they uncover nakedness, if these shed blood, so also do they shed blood. Immediately, Michael will be silent. The Holy One, blessed be He, will say to Michael: You have been brought to silence, but I will speak in defence of My children, and all the deeds of Sammael will have no effect. For thus it was said,

\footnotetext{
${ }^{35}$ Elijah is pictured as coming from God and the Messiah in heaven, thus making him party to the information he is relating to the rabbi. Although it could be denied that Elijah had gone up to heaven (e.g. b. Sukkah 5a), this view is outweighed by the far more frequently attested opinion that he was in heaven and would return with the Messiah (e.g. Gen. Rab. 34.8, b. Sanh. 98a-b, b. B. Meși'a 85b, Sefer Zerubbabel, Otot ha-Mashiah); cf. Theodoret of Cyrus, Comm. Dan. 12.1, who assigns a prominent role to Elijah in the eschatological future as one who announces the coming of Jesus and converts Jews to Christianity. Theodoret also claims that Elijah will be assisted by Michael. On the role of Elijah in rabbinic literature, see Karin Hedner-Zetterholm, "Elijah's different roles: a reflection of the rabbinic struggle for authority," Jewish Studies Quarterly 16.2 (2009): 163-182, Karin HednerZetterholm, "Elijah and the Messiah as spokesmen of rabbinic ideology," in The Messiah in Early Judaism and Christianity, ed. Magnus Zetterholm (Minneapolis: Fortress Press, 2007), 57-78, and Aharon Wiener, The Prophet Elijah in the Development of Judaism (London: Routledge and Kegan Paul, 1978).

36 נחמות דישעיה is a reference to those passages in Isaiah that offer comfort and encouragement to Israel and is a concept with a long literary history; cf. 4Q176, which contains the title "From the Book of Isaiah: Consolations" followed by a quotation of Isa 40:1-3, and Pesiq. Rab Kah. 16.8 and Pesiq. Rab. 29/30B.2, which outline consolations of the prophets.

${ }^{37}$ For MT "your works" (מעשיך), Pirqe Mashiah reads "his works" (מעשיו).

${ }^{38}$ Isa 57:12 is an ironic statement about idolaters in Israel. However, in Pirqe Mashiah the "righteousness" is interpreted positively in relation to Israel and the negative understanding of "works" is applied to Sammael. This presents a reinterpretation of Isa 57:12 to show that, although Sammael brings charges, they come to nothing and Israel's righteousness is proclaimed, which is a prominent theme throughout this compilation.

${ }^{39}$ This identification is also made in טעם אחר in MS Bayerische Staatsbibliothek Cod. Hebr. 222, 83b; cf. Sammael as prince of Esau (סמאל שרו של עשו) in Tanh Wayishlah 8.

40 Jellinek, Bet ha-Midrasch, 3:68.
} 


\begin{abstract}
"I speak righteousness" (Isa 63:1), and I will save them on the Day of Judgement. On account of what righteousness? That Israel accepted the Torah at Mount Sinai, as, if they had not accepted, he would have destroyed the entire world. At once all the heavenly household will respond and say: "Mighty to deliver" (Isa 63:1), mighty is this merit to save them from Gehinnom. And concerning this it was said, "But at that time your people will be delivered-everyone who is found written in the book" (Dan 12:1). By what merit will they be delivered? By the merit of the Torah, because they accepted all that is written in the book. Consequently, it says: "O Israel, and I will testify against you [בך]" (Ps 50:7). ב"ך is by gematria twenty-two, the letters that are in the Torah. This teaches you that the Holy One, blessed be He, will testify to the merit of Israel because they accepted the Torah which was given through twenty-two letters.
\end{abstract}

Pirqe Mashiah presents a late midrashic concept of election history based on Dan 12:1 and Ps 50:7, centred around the importance of Torah, claiming Michael as the defender of Israel, and utilising the prophecy against Edom in Isa 63:1 as biblical evidence. However, in this tradition, Pirqe Mashiah includes a contest between Michael and specifically Sammael, who is already identified as the prince of Rome. The interpretation outlines how God delivers Sammael to Michael, but Sammael argues for the right to disputation, to which God agrees. Thus, a judicial setting is again presented, which again allows for the demonstration and justification of divine justice. Sammael, as Israel's accuser, is presented in diverse rabbinic traditions as coming into conflict with Michael as advocate for Israel. ${ }^{41}$ Sammael was originally one of the chief angels but he fell from heaven, and, as a result, he is often identified with ha-satan. ${ }^{42}$ Sammael's charges against Israel are similar to those outlined in Ruth Rabbah and are typical crimes often brought against the nations, namely, transgression (עוברי עבירה) in general, and specifically sexual immorality (מגלה עריות) and bloodshed (שופכי דמים). As in Ruth Rabbah, Michael is unable to answer Sammael, but explanatory proof texts are not included here, which is a sign of a different exegetical approach in this tradition. God intervenes to save Israel, based on Isa 63:1, which points to the merit Israel acquired for accepting the Torah. The recitation of Isa 63:1 by the heavenly household confirms a favourable verdict due to the merit Israel has attained. ${ }^{43}$ The tradition thus connects the salvation of Israel with allusion to vengeance against Edom through double citation of Isa 63:1. This links with Sammael's role as prince of Rome, and reinforces the identity of Israel's opponents in this interpretation. In this way, Pirqe Mashiah presents a specific eschatological enemy in the form of a representative of 'Rome', and so an overtly politicised form of the tradition is offered. Importantly, this explicit anxiety about 'Rome' is placed in the setting of competing claims centred on Torah as a sign of election.

Dan 12:1 is cited here not to explain the silence of Michael, but to underscore that the merit of accepting the Torah will save Israel from Gehinnom. The verse describes how Michael will arise to defend the cause of the upright, but, although Michael is the protector of all Israel, it is only a remnant that will be saved, namely, "everyone who is found written in the book." A key question in Pirqe Mashiah is who will be saved at the end of time. However, Dan 12:1 is utilised not to show that a remnant as found "written in the book" will be saved, but rather that all Israel will be saved because they accepted what was "written in the book," that is, the Torah. This is further supported by Ps 50:7. In a departure from the peshat understanding of the Psalm,

\footnotetext{
${ }^{41}$ cf. Exod. Rab. 18.5. Pirqe R. El. 26 records that the opposition between these figures began when Sammael was thrown from heaven by God and he tried to take Michael with him by grabbing hold of his wings. For dispute between Michael and Sammael, see Kensky, Trying man, Trying God, 318-319.

${ }^{42}$ For Sammael in rabbinic traditions, see, for example, Gen. Rab. 56.4, b. Soțah 10b, Deut. Rab. 11.10, 3 En. 14.2 and 26.12, Tg. Ps.-J. Gen 3:6, Pirqe R. El. 13-14 and Tanḥ Wayishlaḥ 8. See Günter Stemberger, "Samael und Uzza: Zur Rolle der Dämonen im späten Midrasch," in Die Dämonen, ed. Armin Lange (Tübingen: Mohr Siebeck, 2004), 636-661.

${ }^{43}$ On the heavenly household, see $b$. Hull. 7b, b. Sanh. 67b, b. Ber. 16b; cf. the imperial household, see John Haldon, "The State: Structures and Administration," in The Oxford Handbook of Byzantine Studies, ed. Elizabeth Jeffreys, et al (Oxford: OUP, 2008), 539-553.
} 
"I will testify against you" (אעידה בך) is used to show not that God will testify against Israel, but that God will bear witness on behalf of Israel because they received the Torah. ${ }^{44}$ This understanding is derived from the application of gematria, so the plain sense of בך, "against you," is instead understood in terms of its numerical value of twenty-two, which is said to correspond to the twenty-two letters of the Hebrew alphabet of which the Torah is composed. Thus, the use of gematria on Ps 50:7 intimates God's witness to the merit of Israel for their acceptance of the Torah. ${ }^{45}$ Pirqe Mashiah interprets biblical texts that could be deemed critical of elements within Israel so as to provide a view of election history that is not only for a righteous remnant, as Dan 12:1 might suggest, but for all Israel. This is an emphatic dualistic statement on the future status of all Israel in relation to 'Rome.'46

Unlike Ruth Rabbah, Pirqe Mashiah explicitly identifies 'Rome' as the primary competitor of Israel and offers a perspective on their relative status that leaves no doubt that Israel are God's people. This status is directly linked to the acceptance and proper understanding of Torah. The unequivocal salvation of all Israel in light of competing claims is reflective of the religious competition of the seventh century, a time that bore witness to a changing political and religious landscape across the Eastern Mediterranean and beyond. The emphatic dualism and identification of Israel's opponents are all indicative of this crisis and underscore God's justice on behalf of Israel. In this way, Pirqe Mashiah represents an historical audience of the tradition also preserved in Ruth Rabbah proem 1. The tradition is explicitly understood in relation to Christian 'Rome' by later Jewish exegetes, and so not only presents a reflection on Christian Byzantine society, but supports the trajectory of interpretation proposed for Ruth Rabbah.

\section{Otot ha-Mashiah}

Otot ha-Mashiah is an important apocalyptic work because of its polemical engagement with the 'other', and Daniel 12 features prominently as part of its discourse. ${ }^{47}$ A key feature of this compilation is the circumstances of the rule of wicked Edom. The first sign describes the rule of wicked kings who appear to follow God, but in reality do not do so, and who cause all the nations of the world to become apostates as a result of their laws. It becomes clear that their apostasy is manifested in decrees against the Temple, the Torah and God. In the sixth sign, the evil empire is identified with wicked Edom who has sovereignty over all the world. The compilation describes a final king, explicitly identified as being in Rome, ${ }^{48}$ who brings destruction and holds huge animosity towards Israel. The oft repeated midrashic concern with taxation is mentioned as part of the burden of Edom's rule, as well as restrictive legal edicts that lead to the decline of Israel. ${ }^{49}$ This situation is not contested until the arrival of the Messiah ben Joseph whose role is to defeat the king of Edom. ${ }^{50}$

\footnotetext{
${ }^{44}$ cf. Tanh Buber Wa'era 1 and Tanh Buber Yitro 15.

45 The same interpretation of בך, but in reference to Song 1:4, is found in Pesiq. Rab Kah. 22.2.

46 The apologetic aim of Pirqe Mashiah is highlighted by explicit reference to dispute with a gentile or a heretic (גוי או מין) on questions of the status of Israel and Jerusalem in the future; see note 15.

47 Otot ha-Mashiah is found in Jellinek, Bet ha-Midrasch, 2:58-63; cf. Even-Shemuel, Midreshe Ge'ulah, 318323.

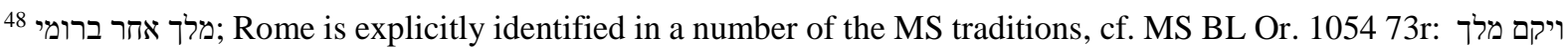
אחד ברומי; MS JER NLI 1142.6=24 1v: ויקום מלך אחר ברומי; MS Leipzig Ms. B.H. qu.38 85v: ויקום מלך אחד ברומי

${ }^{49}$ On taxation and its oppressive nature, see, for example, Gen. Rab. 64.10, Lev. Rab. 29.2, Lam. Rab. 3.3, Ruth Rab. proem 3, Song Rab. 2.8. See also note 15.

${ }^{50}$ The Messiah ben Joseph retrieves the Temple Vessels from Rome as part of his military activities; cf. Boustan, "Spoils of the Jerusalem Temple," 327-372. On the Messiah ben Joseph, see, for example, Martha Himmelfarb, Jewish Messiahs in a Christian Empire (Cambridge, MA: Harvard University Press, 2017), 99-119, David Berger,
} 
There is a special interest in the righteous and the wicked throughout Otot ha-Mashiah, which is extensively explored in relation to religious faithfulness, and the apostasy of the gentile nations. The material draws a sharp contrast between the righteous amongst Israel, the wicked amongst Israel, and the gentile nations in terms of religious commitments. The gentile nations are described as "those who observe worthless vanities" (משרים הבלי שוא; Jonah 2:9), and are inconstant in their commitment to these worthless practices. The wicked of Israel are those who have abandoned all hope of redemption and "commit apostasy against the Holy One, blessed be He" (כופרים בהקב"ה), but the righteous amongst Israel are "those who have maintained faith in the Holy One, blessed be He" (המחזיקי באמונתו של הקב"ה), and will receive reward based on Dan 12:3. The combination of political censure and concern over correct religious observance makes Otot ha-Mashiah a compilation of significant interest for its representation of the 'other' and its use of the Book of Daniel to do so.

Following the Messiah ben Joseph's success against Edom, the seventh sign in Otot haMashiah describes the appearance of Armilus the Satan (ארמי'לוס השטן). ${ }^{51}$ The representation of Armilus in Otot ha-Mashiah can be viewed as a means of critiquing Christian teachings. ${ }^{52}$ Armilus is identified as the figure known as the Antichrist amongst the gentile nations ( זה (שהאומות קורין אותו אנטיקרי'שטו), an explicit title that gives a clear indication of who is understood by "the peoples" in this context. ${ }^{53}$ The first action of Armilus is to go to the Edomites and claim that he is the Messiah and "your God". The Edomite Messiah is thus identified with a deity by Armilus, which does not present Trinitarian subtleties, but is clearly evocative of Christian concepts of messianism. Armilus tells the descendants of Esau: "Bring to me my torah (תורתי) which I gave to you!" and accordingly they bring what is described as "their frivolity" (תפלותם) ${ }^{54}$ Armilus claims this scripture as his revelation, he is affirmed as Messiah, and the

\footnotetext{
'Three Typological Themes in Early Jewish Messianism: Messiah Son of Joseph, Rabbinic Calculations, and the Figure of Armilus', Association for Jewish Studies Review 10 (1985), pp. 141-65, Holger Zellentin, "Rabbinizing Jesus, Christianizing the son of David: the Bavli's approach to the secondary Messiah traditions," in Discussing Cultural Influences: Text, Context, and Non-Text in Rabbinic Judaism, ed. Rivka Ulmer (Lanham: University Press of America, 2007), 99-127.

${ }^{51}$ Cf. MS BL Or. 1054 73v: ארמילים השטן; MS JER NLI 1142.6=24 1r: אורמילוס השטן; MS Leipzig Ms. B.H. qu.38 85v: ארמילוס השטן. Armilus is described as the product of a sexual union between a marble statue in Rome and wicked men from the gentile nations. This tradition is also found in Sefer Zerubbabel where it has been described by David Biale as anti-Christian polemic due to its subversion of the narrative of the virgin birth; cf. David Biale, "Counter-History and Jewish Polemics Against Christianity: The Sefer Toldot Yeshu and the Sefer Zerubavel," Jewish Social Studies n. s. 6 (1999): 130-145. On the figure of Armilus, see Himmelfarb, Jewish Messiahs, 5659, Bernard McGinn, Antichrist: Two Thousand Years of the Human Fascination with Evil (San Francisco, 1994; reprinted, New York: Columbia University Press, 2000), David Berger, "Three Typological Themes in Early Jewish Messianism," 141-65, Joseph Dan, "Armilus: the Jewish Antichrist and the origins and dating of the Sefer Zerubbavel," in Toward the Millennium; Messianic Expectations from the Bible to Waco, ed. Peter Schäfer and Mark Cohen (Leiden: Brill, 1998), 73-104, and Sivertsev, Judaism and Imperial Ideology, 154-158.

52 Armilus in Otot ha-Mashiah is understood by Gerbern Oegema as representing a critique of Christianity: "Abgesehen davon, dass hier die auch aus anderen Apokalypsen bekannten Merkmale des Antichrists beschrieben werden (er verführt die Menschen und sie folgen ihm), fallen zwei Aspekte auf: erstens, dass er christliche Züge hat, zweitens dass die Tora zum Streitpunkt in einer Art „Disputation“ geworden ist”, Oegema, Zwischen Hoffnung und Gericht, 302. Alternatively, Sivertsev emphasises the function of Armilus as representing Christian Roman emperors: "The figure of Armilos personifies more than just Rome. It personifies the Christian revival of the Roman Empire, serving almost as a caricature of Eusebius' Constantine and subsequent emperors who modelled themselves on Constantine," Sivertsev, Judaism and Imperial Ideology, 155.

${ }^{53}$ The Christian term 'Antichrist' is explicitly identified in a number of the MS traditions; cf. MS BL Or. 1054 73v: וזהו שקורין אונטקרישט בלעז; (ט) 'וזיש: MS JER NLI 1142.6=24 1r: זומות העו' קורין אותו אנטקרשטו; MS Leipzig Ms.

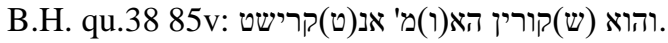

${ }^{54}$ Reference to the frivolity of the torah of the nations is found in a number of manuscripts, including specific

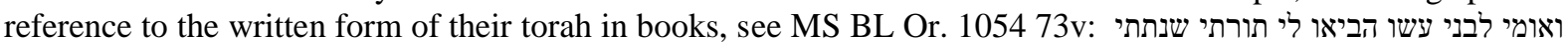
ואומר לבני עשו הביאו אלי :and MS Leipzig Ms. B.H. qu.38 85v-86a לכם וכל אומות העולם מביאים לו כל ספרי תיפלותיהם
} 
nations "immediately put their trust in him". The description of the sacred texts of the nations as "frivolity" goes beyond the purely political realm to highlight the importance of scripture as a focus of dispute. Thus, the "Edomite" religion is portrayed as one concerned with messianism and scripture, but Otot ha-Mashiah ridicules this alternative belief system, which is underscored by the fact that their adherents are duped by a satanic figure.

The question of competing scriptures and the Torah as a focus of dispute is further accentuated in the actions of the Messiah ben Joseph. ${ }^{55}$ Armilus calls for Nehemiah, the Messiah ben Joseph, and requests that he bring the Torah and use it to testify that Armilus is God. However, Nehemiah reads out the commandment in Exod 20:3: "you shall have no other Gods before me". Armilus denies that this is in the Torah and reiterates his divine claim. The Messiah ben Joseph is not deceived and goes into battle against Armilus. This tradition presents a view of election history that is based on the acceptance of Torah and adherence to it. Torah is central to Israel's deliverance at the end of time, as it is only knowledge of Torah that highlights the fraudulent nature of the claims made by Armilus, and allows God's people to navigate the eschatological tribulations they must face. In this way, the tradition also reinforces the necessity of Torah study in this world in preparation. This emphasis on the importance of correct understanding of Torah is, of course, central and longstanding within Jewish traditions, but is also a major source of controversy in light of Christian claims for their form and understanding of scripture.

Following the defeat of Nehemiah, the Messiah ben Joseph, at the hands of Armilus, Israel lose courage and suffer at the hands of the nations of the world. It is at this point that Michael arrives on the scene:

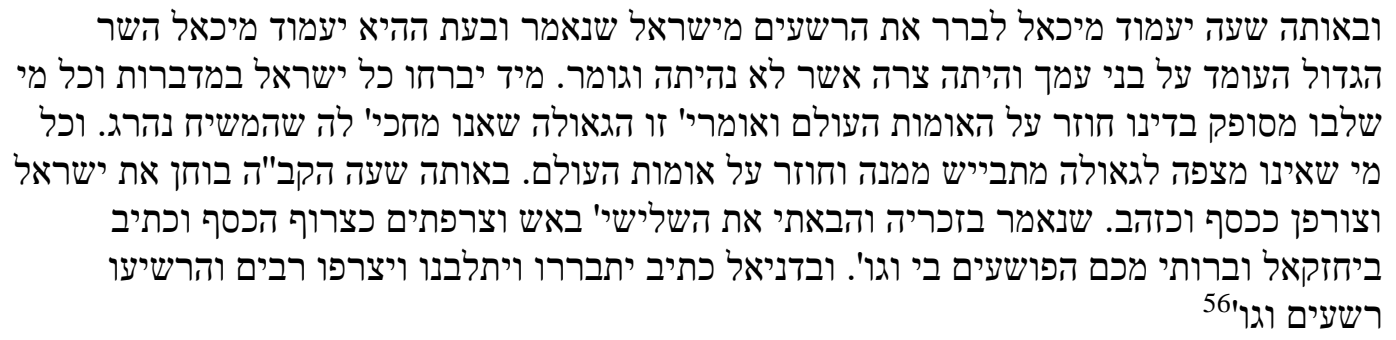

\begin{abstract}
At that moment, Michael will arise to purge the wicked from Israel, as it is said, "At that time, Michael, the great prince, the one who protects the children of your people, will arise. There will be distress such as has not happened, etc." Immediately, all Israel will flee into the deserts, and everyone whose heart doubts his judgement will turn to the peoples of the world and say: Is this the redemption for which we have been hoping, for the Messiah has been killed! And everyone who is no longer waiting for redemption will be ashamed on account of it, and will turn to the peoples of the world. At that moment, the Holy One, blessed be He, will test Israel and refine them like silver and like gold, as it is said in Zechariah: "And I will bring the third part into the fire, and I will refine them as one refines silver" (Zech 13:9), and it is written in Ezekiel: "And I will purge from among you the ones who transgress against me, etc." (Ezek 20:38), and in Daniel it is written: "Many will be purged and be made white and be refined, but the wicked will behave wickedly, etc." (Dan 12:10).
\end{abstract}

At the (temporary) victory of Armilus, Israel will experience distress such has never happened in the history of creation, including expulsion from the lands of the nations of the world. This provides the opening for citation of Dan 12:1 as Michael is said to arise at a time of major distress. In an allusion to Dan 12:10, Michael's function is "to purge the wicked from Israel"

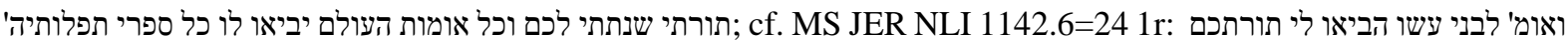

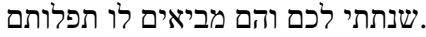

${ }^{55}$ See note 30 above on competition over scripture.

${ }^{56}$ Jellinek, Bet ha-Midrasch, 2:61.
} 
who are found amongst the survivors of the eschatological battles, and so Michael is acting both as advocate and judge. Unlike Ruth Rabbah and Pirqe Mashiah, which interpret Dan 12:1 in terms of the salvation of Israel as a whole, the tradition in Otot ha-Mashiah focuses on how only a righteous remnant who are recorded in "the book" will be saved. Israel flee to the desert and the tradition describes how some "cast doubt" (שלכו מסופק) on redemption due to the death of the Messiah ben Joseph. However, this is not simply doubts about their status and promises of salvation, but explicitly goes as far as turning to the peoples of the world, which reflects a particular concern for religious faithfulness in light of the 'other'. It is at this point that God (not Michael) tests Israel. The testing of Israel is also seen as fulfilment of biblical prophecy, as found in Zech 13:9, Ezek 20:38 and Dan 12:10, which are linked on the basis of references to purging (צרר) and refining (צרף), which is also the same terminology used in the description of Michael's role to purge (לברר) the wicked from Israel. ${ }^{57}$ Only those who remain faithful will be deemed part of the wise and righteous remnant, and the wicked, or those who commit apostasy, will be judged as unworthy of receiving redemption and destroyed. The importance of Daniel 12 is reiterated in the remainder of the tradition, as the purified remnant are said to be in the wilderness for a period of forty-five days before the final eschatological events, based on the difference between the 1,290 days of Dan 12:11 and the 1,335 days of Dan 12:12. ${ }^{58}$

Having criticized the power and religion of Edom, Otot ha-Mashiah utilises Dan 12:1, and indeed a number of verses from Daniel 12, to provide a vision of the end of time that highlights Israel's elect status. Michael is the advocate of Israel, but is also active in judgement against the wicked amongst them. As such, it is not all Israel that will receive the reward of redemption in the compilation, but only those who prove themselves to be faithful through proper adherence to the Torah and avoidance of apostasy. The message is clear that all those deemed wicked by virtue of their apostasy will be destroyed because they are unworthy of experiencing deliverance. This concern over apostasy in Otot-ha-Mashiah reflects a time of uncertainty, where competing claims over scripture and religious authority are again at stake in the seventh century. This apocalyptic compilation sends a warning that only those faithful to the 'proper' understanding of Torah will be saved, and simultaneously ridicules the Christian rivals of faithful Israel. Armilus is eventually defeated by God, along with his supporters who are identified as "wicked Edom who destroyed the Temple of our God and exiled us from our land". Thus, a key aim of the compilation is to show that the rivalry between Israel and Edom will ultimately be resolved in favour of Israel, as is highlighted through citation of Obad 1:18: "The house of Jacob will become fire, and the house of Joseph will be a flame, and the house of Esau will serve as dry chaff."

\section{Conclusions}

To return to the questions raised at the start of this paper: First, how is Dan 12:1 interpreted to explain the trajectory of Jewish history, and what do the different rabbinic and apocalyptic

\footnotetext{
${ }^{57}$ Zech 13:9 refers to an eschatological future where the sheep (i.e. Israel) will be tested, but with only a third surviving to undergo this test, cf. Song Rab. 1.22; Ezek 20:38 warns Israel (originally those in exile) that those who rebel against God from among them will be judged, cf. Tanh Buber Beha'alotekha 13 and Num. Rab. 15.12; Dan 12:10 is part of an apocalyptic vision of the fate of the righteous and the wicked - the wise will understand and purify themselves whereas the wicked will be in ignorance and continue to behave wickedly.

${ }^{58}$ Cf. Hippolytus, Scholia on Dan. 12.1 and 12.9, Cyril of Jerusalem, Catechetical Lectures 15.16-17, Jerome, Comm. Dan. 12.12, John Chrysostom, Discourses against Judaizing Christians 5.8.4, Theodoret of Cyrus, Comm. Dan. 12.1 and 12.12. This passage from Otot ha-Mashiah has also been discussed in relation to the development of a discourse in apocalyptic literature regarding doubt over the claims of apocalyptic figures in Helen Spurling, "Discourse of Doubt: The Testing of Apocalyptic Figures in Jewish and Christian Traditions of Late Antiquity," Jewish Culture and History 16.3 (2015): 109-126.
} 
traditions suggest about perceptions of the place of Israel in broader society? Each of the traditions examined outline the relative fates of Israel and the nations in terms of God's justice at the end of time. Ruth Rabbah focuses on the expression יעמד מיכאל and the inability of Michael to act in his role as advocate for Israel when he stands silent. His function is subordinated to that of God as the ultimate deliverer of all Israel, and Israel will be saved because of their acceptance of Torah. Pirqe Mashiah also reports the silence of Michael in the divine court, but interprets כתוב בספר in Dan 12:1 as strong evidence that all Israel will be saved because they accepted what was written in "the book" or Torah, which is contrasted with the fate of the nations and particularly Rome as represented by Sammael. In Otot ha-Mashiah, Michael appears at a time of eschatological turmoil based on והיתה עת צרה, but, in this כל הנמצא כתוב compilation, it is a righteous remnant who will be saved as in the expression בספר. This is critical of unfaithful elements within Israel, as well as the nations, and sees Michael's function as a judge who determines proper adherence to Torah as part of the tribulations of the end. As such, with different emphases, all of these exegetical approaches highlight eschatological concepts of election history centred on Torah as a reflection of God's long-term plan and vision for the world. ${ }^{59}$ The trajectory of Jewish history revolves around Torah: Israel accepted the Torah as a sign of their relationship with God in the past; adherence to Torah in the present is a means of continuing that relationship; and it is acceptance and knowledge of Torah that will ensure their redemption in the future. This Torahcentric vision of the progress of history serves to reinforce the elect status of Israel within the world in a period when historical reality may have suggested otherwise, and in turn supports the authority of rabbinic leadership as the ones who in this world provide proper guidance on Torah.

Secondly, what evidence do the rabbinic and apocalyptic traditions provide of perceptions of Christian Byzantine rule or Christian teachings, and what is the nature of those reflections? The fact that concepts of election feature prominently in rabbinic traditions is not surprising. In the interpretations analysed here, the Book of Daniel has been used to claim authority for Israel's religious tradition, and to understand their place in the world in light of historical reality. Still, historical reality for Palestinian Jews in Late Antiquity meant living under almost uninterrupted Christian rule from the time of Constantine until the seventh century, and, to different degrees, it is possible to understand each tradition as revealing perceptions of the broader Christian environment. Who will be saved and who are the key opponents of Israel are key questions, and a marker of the particular concerns of the traditions.

Ruth Rabbah is the most allusive of the traditions assessed. It outlines dualistic opposition to the peoples of the world centred on Torah, and implies critique of Edom in particular in its use of proof texts. The downplaying of the role of Michael may also be a response to Christian appropriation of this biblical figure. Although other readings are possible given that it does not provide explicit evidence, such a teaching in circulation at the time of Ruth Rabbah's compilation could be understood as alluding to the contemporary ruling powers, who also happened to hold a claim on scripture and emphasised their elect status as Verus Israel. Torah and election are foundational concepts within rabbinic exegesis, but countering Christian claims and emphasising traditional ideas can go hand in hand, and it is telling that concepts of election are so prominent in a period in confrontation with Christian claims. ${ }^{60}$ Pirqe Mashiah addresses similar themes, but explicitly identifies the chief opponent of Israel as Sammael, the prince of Rome. What could arguably have been read as a statement on the

\footnotetext{
${ }^{59}$ Oegema draws a distinction between history and holy history, the latter of which is connected to concepts of God's justice, see Oegema, Zwischen Hoffnung und Gericht, 45.

${ }^{60}$ Günter Stemberger, "Rabbinic Reactions to the Christianization of Roman Palestine: A Survey of Recent Research," in Encounters of the Children of Abraham from Ancient to Modern Times, ed. Antti Laato and Pekka Lindqvist (Leiden: Brill, 2010), 157.
} 
relationship between Israel and the Christian Byzantine ruling power in Ruth Rabbah, was explicitly read so by the next generation as manifested in Pirqe Mashiah, which provides an historical audience for Ruth Rabbah and evidence for interpretation of the tradition preserved in Ruth Rabbah proem 1 in light of the Christian Byzantine world. The compilation presents clear criticism of Byzantine power, but with the Torah and election as the means of distinguishing between Israel and their rivals so moving beyond the political to religious sphere. Pirqe Mashiah is especially emphatic that it is all Israel who will be saved, which may well reflect that such an unequivocal apologetic statement was needed when it was compiled. Otot ha-Mashiah emphasises the importance of "the book", and proper understanding of scripture as an issue of dispute is explored. This is combined with critique of Christian messianic concepts, as well as the ruling power of Edom. Overall, Otot ha-Mashiah is much more polemical in tone, and reflects explicit engagement with the Christian 'other'.

Thus, the exegesis of Daniel examined here can provide an indication of perceptions of Christian teachings and rule in the Byzantine world. Indeed, each interpretation reflects the historical circumstances in which they were compiled. Ruth Rabbah follows the traditional rabbinic approach of allusion when it comes to critique of the dominant power. However, Otot ha-Mashiah and Pirqe Mashiah were compiled at the time of, or recently after, the decline of the Byzantine Empire in the Eastern Mediterranean, and so were produced when the hoped for vengeance against 'Edom' could be realised. ${ }^{61}$ These historical circumstances may explain the more open identification of Israel's opponents in Pirqe Mashiah and Otot ha-Mashiah. In addition, the more allusive nature of Ruth Rabbah in comparison to the traditions in Pirqe Mashiah and Otot ha-Mashiah raises the question as to whether the genre of writing has an impact on the level of acknowledgement of the Christian world. It is likely that the apocalyptic genre, and the type of language associated with it, allows for more freedom of expression, and the moral dualism typical of apocalyptic works results in more overt apology (Pirqe Mashiah) or even polemic (Otot ha-Mashiah).

Overall, the traditions examined have different emphases, but can be read as portraying a view of election history in dualistic opposition to the Christian 'other'. This opposition is directed against Byzantine political rule and its anticipated end, and theological ideas centred on election and acceptance and 'proper' understanding of Torah. The different emphases of the exegesis reflect historical change, especially with regard to the changing religio-political circumstances of the seventh century and an environment of increasing religious competition. It is hoped that this preliminary investigation into an aspect of the reception of the Book of Daniel can, on a case by case basis, provide evidence of perceptions of the Christian 'other', and contribute one approach to Jewish-Christian relations after Constantine.

\footnotetext{
${ }^{61}$ Arab conquest and rule meant that 'Edom' was defeated in the Eastern Mediterranean. See Nistarot R. Shimon ben Yohai in Jellinek, Bet ha-Midrasch, 3:78. For views on the Muslim 'other', see, for example, Robert Hoyland, Seeing Islam As Others Saw It: A Survey and Evaluation of Christian, Jewish and Zoroastrian Writings on Early Islam (Princeton, NJ: Darwin Press, 1997), Jacob Lassner, Jews, Christians, and the abode of Islam: modern scholarship, medieval realities (Chicago: University of Chicago Press, 2012), Carol Bakhos, Ishmael on the border: rabbinic portrayals of the first Arab (Albany: State University of New York Press, 2006), and Reeves, Trajectories, 1-24.
} 


\section{Bibliography}

Avery-Peck, Alan, and Jacob Neusner, eds. Death and afterlife in the early rabbinic sources: The Mishnah, Tosefta, and early Midrash compilations. Leiden: Brill, 2000.

Bakhos, Carol. Ishmael on the border: rabbinic portrayals of the first Arab. Albany: State University of New York Press, 2006.

Bakhos, Carol. "Figuring (out) Esau: The Rabbis and Their Others." Journal of Jewish Studies 58.2 (2007): 250-262.

Bakhos, Carol, ed. Current Trends in the Study of Midrash. Leiden: Brill, 2006.

van Bekkum, Wout J. "Four Kingdoms will Rule: Echoes of Apocalypticism and Political Reality in Late Antiquity and Medieval Judaism." In Endzeiten: Eschatologie in den monotheistischen Weltreligionen, edited by Wolfram Brandes and Felicitas Schmieder, 101-118. Berlin; New York: de Gruyter, 2008.

Berger, David. "Three Typological Themes in Early Jewish Messianism: Messiah Son of Joseph, Rabbinic Calculations, and the Figure of Armilus." Association for Jewish Studies Review 10 (1985): 141-65.

Biale, David. "Counter-History and Jewish Polemics Against Christianity: The Sefer Toldot Yeshu and the Sefer Zerubavel." Jewish Social Studies n. s. 6 (1999): 130-145.

Boustan, Ra 'anan. "The Spoils of the Jerusalem Temple at Rome and Constantinople: Jewish CounterGeography in a Christianizing Empire." In Antiquity in Antiquity: Jewish and Christian Pasts in the Greco-Roman World, edited by Gregg Gardner and Kevin L. Osterloh, 327-372. Tübingen: Mohr Siebeck, 2008.

Braverman, Jay. Jerome's commentary on Daniel: A Study of Comparative Jewish and Christian Interpretations of the Hebrew Bible. Washington DC: The Catholic Biblical Association of America, 1978.

Buttenwieser, Moses. Die hebräische Elias-Apokalypse. Leipzig, 1897.

Cohen, Gerson. "Esau as Symbol in Early Medieval Thought." In Jewish Medieval and Renaissance Studies, edited by Alexander Altmann, 19-48. Cambridge MA: Harvard University Press, 1967.

Collins, Adela Y., and John J. Collins. King and Messiah as Son of God. Grand Rapids: Eerdmans Publishing Co., 2008.

Collins, John J., and Peter W. Flint, eds. The Book of Daniel: Composition and Reception. Leiden: Brill, 2002.

Collins, John J. Daniel: a commentary on the Book of Daniel. Minneapolis: Fortress Press, 1993.

Dan, Joseph. "Armilus: The Jewish Antichrist and the origins and dating of the Sefer Zerubbavel." In Toward the Millennium; Messianic Expectations from the Bible to Waco, edited by Peter Schäfer and Mark Cohen, 73-104. Leiden: Brill, 1998.

DiTommaso, Lorenzo. The Book of Daniel and the Apocryphal Daniel Literature. Leiden: Brill, 2005.

Even-Shemuel, Yehuda. Midreshe Ge'ulah. Jerusalem-Tel Aviv: Bialik Insitute, 1953-4. 
Goldenberg, Robert. The Nations that Know Thee Not: Ancient Jewish Attitudes towards Other Religions. Sheffield: Sheffield Academic Press, 1997.

Goodman Martin, and Philip Alexander, eds. Rabbinic Texts and the History of Late-Roman Palestine. Oxford: OUP, 2010.

Grypeou, Emmanouela, and Helen Spurling. The Book of Genesis in Late Antiquity: Encounters between Jewish and Christian Exegesis. Leiden: Brill, 2013.

Hadas-Lebel, Mireille. Jerusalem against Rome. Leuven; Dudley MA: Peeters, 2006.

Haldon, John. "The State: Structures and Administration." In The Oxford Handbook of Byzantine Studies, edited by Elizabeth Jeffreys, 539-553. Oxford: OUP, 2008.

Hannah, Darrell. Michael and Christ. Tübingen: Mohr Siebeck, 1999.

Hedner-Zetterholm, Karin. "Elijah's different roles: a reflection of the rabbinic struggle for authority." Jewish Studies Quarterly 16.2 (2009): 163-182.

Hedner-Zetterholm, Karin. "Elijah and the Messiah as spokesmen of rabbinic ideology." In The Messiah in Early Judaism and Christianity, edited by Magnus Zetterholm, 57-78. Minneapolis: Fortress Press, 2007.

Hezser, Catherine. "Classical Rabbinic Literature." In The Oxford Handbook of Jewish Studies, edited by Martin Goodman, 115-140. Oxford: OUP, 2005.

Hidary, Richard. Rabbis and Classical Rhetoric. Cambridge: CUP, 2018.

Himmelfarb, Martha. Jewish Messiahs in a Christian Empire. Cambridge, MA: Harvard University Press, 2017.

Hirshman, Marc. “Election and rejection in the Midrash.” Jewish Studies Quarterly 16.1 (2009): 71-82.

Horbury, William. Messianism among Jews and Christians. London; New York: T\&T Clark, 2003.

Hoyland, Robert. Seeing Islam As Others Saw It: A Survey and Evaluation of Christian, Jewish and Zoroastrian Writings on Early Islam. Princeton, NJ: Darwin Press, 1997.

Hurtado, Larry W., and Paul L. Owen. Who is this Son of Man? London; New York: T\&T Clark International, 2011.

Jellinek, Adolph. Bet ha-Midrasch. Jerusalem: Bamberger \& Wahrmann, 1938.

Kannengiesser, Charles. Handbook of patristic exegesis: The Bible in ancient Christianity. Leiden; Boston: Brill, 2004.

Kensky, Meira Z. Trying man, Trying God: The Divine Courtroom in Early Jewish and Christian Literature. Tübingen: Mohr Siebeck, 2010.

Lassner, Jacob. Jews, Christians, and the abode of Islam: modern scholarship, medieval realities. Chicago: University of Chicago Press, 2012. 
Lerner, Myron B. "The Works of Aggadic Midrash and the Esther Midrashim." In The Literature of the Sages, Part 2, edited by Shmuel Safrai, 133-230. Assen: Royal van Gorcum and Fortress Press, 2006.

McGinn, Bernard. Antichrist: Two Thousand Years of the Human Fascination with Evil. San Francisco, 1994; reprinted, New York: Columbia University Press, 2000.

Mulder, Martin J., and Harry Sysling, eds. Mikra: Text, Translation, Reading and Interpretation of the Hebrew Bible in Ancient Judaism and early Christianity. Philadelphia: Fortress Press, 1988.

Oegema, Gerbern. Apocalyptic Interpretation of the Bible. London; New York: T\&T Clark International, 2012.

Oegema, Gerbern. Zwischen Hoffnung und Gericht: Untersuchungen zur Rezeption der Apokalyptik im frühen Christentum und Judentum. Düsseldorf: Neukirchener Verlag, 1999.

Reeves, John C. Trajectories in Near Eastern Apocalyptic: a postrabbinic Jewish apocalypse reader. Leiden; Boston: Brill, 2006.

Saebo, Magne, ed. Hebrew Bible/Old Testament. Göttingen: Vandenhoeck and Ruprecht, 2000.

Septimus, Yehuda. On the Boundaries of Talmudic Prayer. Tübingen: Mohr Siebeck, 2015.

Schäfer, Peter. The Jewish Jesus: How Judaism and Christianity Shaped Each Other. New Jersey: Princeton University Press, 2012.

Schäfer, Peter. "Israel und die Völker der Welt." Frankfurter Judaistische Beiträge 4 (1976): 32-62.

Sivertsev, Alexei M. Judaism and Imperial Ideology in Late Antiquity. Cambridge: CUP, 2011.

Spurling, Helen. "A Revival in Jewish Apocalyptic? Change and continuity in the seventh-eighth centuries with special reference to Pirqe Mashiah." In Apocalypticism and Eschatology in Late Antiquity: Encounters in the Abrahamic Religions, 6th-8th Centuries, edited by Hagit Amirav, Emmanouela Grypeou and Guy Stroumsa, 163-186. Leuven, Peeters Publishers, 2017.

Spurling, Helen. "Discourse of doubt: the testing of apocalyptic figures in Jewish and Christian traditions of late Antiquity." Jewish Culture and History 16.3 (2015): 109-126.

Spurling, Helen. "The Biblical Symbol of Edom in Jewish Eschatological and Apocalyptic Imagery." In Sacred Text: explorations in lexicography, edited by Angel Urban and Juan Pedro Monferrer-Sala, 271-299. Frankfurt: Peter Lang, 2009.

Stemberger, Günter. "Rabbinic Reactions to the Christianization of Roman Palestine: A Survey of Recent Research." In Encounters of the Children of Abraham from Ancient to Modern Times, edited by Antti Laato and Pekka Lindqvist, 141-164. Leiden: Brill, 2010.

Stemberger, Günter. "Die jüdische Danielrezeption seit der Zerstörung des zweiten Tempels am Beispiel der Endzeitberechnung." In Judaica Minora, Teil I: Biblische Traditionen im rabbinischen Judentum, 203-220. Tübingen: Mohr Siebeck, 2010.

Stemberger, Günter. "Aktuelle Probleme in der Erforschung der rabbinischen Literatur: Überlegungen zur Abgrenzung von Werk, Redaktion, Textgeschichte." Frankfurter Judaistische Beiträge 35 (2009): 1-18. 
Stemberger, Günter. "Samael und Uzza: Zur Rolle der Dämonen im späten Midrasch.” In Die Dämonen, edited by Armin Lange, 636-661. Tübingen: Mohr Siebeck, 2004.

Stemberger, Günter. "Zur Auferstehungslehre in der rabbinischen Literatur.” Kairos 15 (1973): 238266.

Strack, Hermann, and Günter Stemberger. Introduction to the Talmud and Midrash, trans. Marcus Bockmuehl. Edinburgh: T\&T Clark, 1991.

Sysling, Harry. Tehiyyat ha-metim: the resurrection of the dead in the Palestinian Targums of the Pentateuch and parallel traditions in classical rabbinic literature. Tübingen: Mohr Siebeck, 1996.

Weiss, Dov. Pious Irreverence: Confronting God in Rabbinic Judaism. Philadelphia: University of Pennsylvania Press, 2017.

Wiener, Aharon. The Prophet Elijah in the Development of Judaism. London: Routledge and Kegan Paul, 1978.

Zellentin, Holger. "Rabbinizing Jesus, Christianizing the son of David: the Bavli's approach to the secondary Messiah traditions." In Discussing Cultural Influences: Text, Context, and Non-Text in Rabbinic Judaism, edited by Rivka Ulmer, 99-127. Lanham: University Press of America, 2007. 